\title{
Вплив карбоксиперитонеуму на серцевий індекс у пацієнтів з морбідним ожирінням та супутньою серцево-судинною патологією під час лапароскопічних баріатричних втручань
}

\author{
В. І. Чернійй ${ }^{1}$ В. В. Євсеєва ${ }^{1}$, В. Г. Гур'янов ${ }^{1,2}$
}

${ }^{1}$ Науково-практичний центр профілактичної та клінічної медицини ДУС, м. Київ,

${ }^{2}$ Національний медичний університет імені О. О. Богомольця, м. Київ

\section{Impact of carboxyperitoneum on cardiac index in patients with morbid obesity and concurrent cardio-vascular pathology during laparoscopic bariatric interventions}

\author{
V. I. Cherniy ${ }^{1}$, V. V. Yevsieieva ${ }^{1}$, V. G. Gurianov ${ }^{1,2}$ \\ ${ }^{1}$ Scientific-Practical Centre of Prophylactic and Clinical Medicine, Kyiv, \\ ${ }^{2}$ Bogomolets National Medical University, Kyiv
}

\section{Реферат}

Мета. Дослідити вплив карбоксиперитонеуму на показники центральної гемодинаміки у пацієнтів 3 морбідним ожирінням (МО) та супутньою серцево-судинною патологією (ССП) під час лапароскопічних баріатричних втручань. Матеріали і методи. В дослідження включено 45 хворих з МО та індексом маси тіла 37 - 58 кг/м² віком від 18 до 61 року, яким були виконані лапароскопічні баріатричні втручання. Супутня ССП виявлена у 100\% пацієнтів. Всім пацієнтам під час операції проведена комбінована інгаляційна низькопотокова анестезія севофлюраном у поєднанні з періопераційною мультимодальною аналгезією. Аналізували показники центральної гемодинаміки, отримані математичним шляхом. Статистичне опрацювання результатів дослідження здійснювали за допомогою пакета аналізу статистичних даних MedCalc v. 18.11 (MedCalc Software Inc, Broekstraat, Бельгія).

Результати. Проведеним кореляційним аналізом встановлено, що зміна абсолютного значення показника серцевого індексу (СI) корелює із внутрішньочеревним тиском (ВЧТ) в умовах карбоксиперитонеуму. Виявлено сильний позитивний лінійний зв'язок $(\mathrm{r}=0,83 ; \mathrm{p}<0,001)$ величини $\Delta \mathrm{CI}$ та ВЧТ. Критичне значення ВЧТ за умови карбоксиперитонеуму становить 15 мм рт. ст.: чутливість - 93,1\% (95\% вірогідний інтервал - ВI 77,2\% - 99,2\%), специфічність - 100\% (95\% ВІ 79,4\% - 100\%), прогностичність позитивного результату - 100\% (95\% ВІ 93,2\% - 100\%), прогностичність негативного результату - 88,9\% (95\% BI 67,7\% - 96,8\%).

Висновки. Тривалий карбоксиперитонеум за тиску 15 мм рт. ст. не призводить до значних гемодинамічних змін у хворих з МО та супутньою ССП і $є$ для них оптимальним.

ключові слова: морбідне ожиріння; анестезія; гемодинаміка; лапароскопія; карбоксиперитонеум.

Abstract

Objective. To investigate the impact of carboxyperitoneum on indices of central hemodynamics in patients, suffering morbid obesity (MO) and concurrent cardio-vascular pathology (CVP) during laparoscopic bariatric interventions.

Materials and methods. In the investigation 45 patients, having $\mathrm{MO}$ and the body mass index $37-58 \mathrm{~kg} / \mathrm{M}^{2}$, ageing from 18 to 61 yrs old, were included, in whom laparoscopic bariatric interventions were performed. Concurrent CVP was revealed in $100 \%$ of the patients. In all the patients intraoperatively a combined inhalation low-streaming anesthesia with sevofluran in combination with perioperative multimodal anesthesia was conducted. Indices of central hemodynamics were obtained mathematically. Statistical elaboration of the investigation result was done with the help of the pool analysis of statistical data MedCalc $\mathrm{v}$. 18.11 (MedCalc Software Inc, Broekstraat, Belgium).

Results. Using correlation analysis there was established, that a change of absolute value of the cardiac index (CI) correlates with intraabdominal pressure (IAP) in setting of carboxyperitoneum. Strong positive linear link was revealed $(r=0.83 ; \mathrm{p}<0.001)$ between values $\Delta$ CI and IAP. Critical value of IAP in environment of carboxyperitoneum constitutes $15 \mathrm{~mm} \mathrm{Hg:} \mathrm{sensitivity} \mathrm{-} \mathrm{93.1 \%}$ (95\% CI - BI 77.2\% - 99.2\%), specificity - 100\% (95\% BI 79.4\% - 100\%), prognostication of positive result - 100\% (95\% BI 93.2\% - 100\%), prognostication of negative result - 88.9\% (95\% BI 67.7\% - 96.8\%).

Conclusion. Durable carboxyperitoneum in pressure $15 \mathrm{~mm} \mathrm{Hg}$ do not lead to significant hemodynamical changes in patients with $\mathrm{MO}$ and coexistent CVP and is optimal for them.

Keywords: morbid obesity; anesthesia; hemodynamics; laparoscopy; carboxyperitoneum.

Переваги лапароскопічного доступу над лапаротомією важко переоцінити: зменшення інтенсивності післяопераційного болю, ранні активізація пацієнтів та початок ентерального харчування, значне скорочення строків госпіталізації. Лапароскопічне шунтування шлунка (ЛШШ) та ла- пароскопічна повздовжня резекція шлунка (ЛПРШ) стали найпоширенішими хірургічними втручаннями у хворих з морбідним ожирінням (МО). Це складні операції, часто більш тривалі, ніж інші лапароскопічні процедури, тому досі точаться дискусії з приводу потенційного несприят- 
ливого впливу тривалого (більше 3 год) карбоксиперитонеуму на серцево-судинну та дихальну функції.

Введення газу в черевну порожнину зазвичай підвищує середній артеріальний тиск ( $\mathrm{AT}_{\text {ср. }}$ ) та частоту серцевих скорочень (ЧСС) [1, 2]. У пацієнтів з нормальною масою тіла дослідники виявили зниження серцевого викиду (CB) та зміни інтервалу QT під впливом пневмоперитонеуму [3, 4]. Водночас є повідомлення про мінімальний гемодинамічний ефект пневмоперитонеуму щодо серцевої функції [5]. Даних про вплив карбоксиперитонеуму на гемодинамічні показники пацієнта під час баріатричного втручання небагато. Відомо, що карбоксиперитонеум пов'язаний з системною абсорбцією вуглекислого газу, що може призвести до гіперкапнії та ацидозу [4, 6]. Крім того, підвищений внутрішньочеревний тиск (ВЧТ) і зворотне положення Тренделенбурга, в якому перебуває пацієнт на операційному столі під час ЛПРШ та ЛШШ, можуть перешкоджати венозному поверненню, зниженню CВ та є факторами ризику розвитку венозного застою в нижніх кінцівках [7]. Оскільки хворі з МО мають дуже варіабельну супутню ССП, вивчення впливу підвищеного ВЧТ під час накладення карбоксиперитонеуму на показники центральної гемодинаміки та корекція їх порушень є одним 3 ключових напрямків у баріатричній анестезіології.

Мета дослідження: вивчити вплив підвищеного ВЧТ в умовах карбоксиперитонеуму на показники центральної гемодинаміки у хворих з МО та супутньою ССП під час лапароскопічних баріатричних втручань; визначити оптимальний ВЧТ під час накладення карбоксиперитонеуму, що не призводить до критичних змін показників гемодинаміки у цієї групи пацієнтів.

\section{Матеріали і методи дослідження}

У дослідження включено 45 хворих з МО та індексом

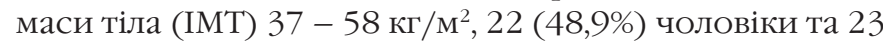
(51,1\%) жінки віком від 18 до 61 року, яким за період з 2015 по 2018 р. в Науково-практичному центрі профілактичної та клінічної медицини ДуС виконані лапароскопічні баріатричні втручання: ЛШШ - 4, ЛПРШ - 41. Всі пацієнти обстежені перед оперативним втручанням згідно з діючим протоколом. Супутня ССП виявлена у 100\% пацієнтів: гіпертонічна хвороба - у 42, серцева недостатність 2А ступеня - у 32, дилатаційна кардіоміопатія - у 5 . Вихідний серцевий індекс (CI) визначали під час проведення ехокардіографіі.

Всім пацієнтам під час операції була проведена комбінована інгаляційна низькопотокова анестезія севофлюраном у поєднанні з періопераційною мультимодальною аналгезією.

Використовували метод багатокомпонентної збалансованої анестезії за такою методикою: премедикація - ондансетрон 8 мг, декскетопрофен 50 мг, пантопразол 40 мг внутрішньовенно; індукція пропофолом - $2-2,5$ мг/кг фракційно до досягнення клінічних симптомів наркозу, 0,005\% розчин фентанілу 0,1 - 0,2 мг або налбуфін 100 200 мкг/кг маси тіла. Інтубація трахеї після релаксації на тлі атракурію безилату в дозі 500 - 600 мг/кг або рокуронію броміду в дозі 0,6 - 1,0 мг/кг. Підтримка анестезії: киснево-севофлюранова суміш ( $\mathrm{FiO}_{2} 50$ - 55\%), севофлюран
(1,4 - 1,7 об.\% на видиху) за швидкості потоку не більше 1 л/хв. Показники біспектрального індексу (BIS) підтримували на рівні 40 - 55. 3 метою інтраопераційного знеболювання виконували місцеву анестезію зон введення троакарів розчином бупівакаїну, вводили парацетамол 1000 мг внутрішньовенно краплинно (до початку накладення карбоксиперитонеуму), фентаніл внутрішньовенно в дозі 2 - 2,5 мкг/кг/атм/год або налбуфін внутрішньовенно в дозі 250 - 500 мкг/кг кожні 30 хв. Релаксацію підтримували фракційним введенням атракурію безилату в дозі 10 20 мг кожні 30 - 40 хв або рокуронію броміду в тій же дозі.

Карбоксиперитонеум накладали інсуфлятором Olympus UHI-3 (Токіо, Японія) через троакар за швидкості потоку 12 л/хв. Цільовий ВЧТ 17 - 18 мм рт. ст.

Інтраопераційний моніторинг пацієнта включав: неінвазивне вимірювання АТ, ЧСС, пульсоксиметрію, електрокардіографію, визначення показників центральної гемодинаміки (математичним методом), концентрації кисню, вуглекислого газу та інгаляційного анестетика на вдиху і видиху, реєстрацію BIS в режимі online. Так само інтраопераційно визначали показники кислотно-лужного стану, рівні електролітів, глюкози крові, венозної сатурації. Всім пацієнтам виконали катетеризацію периферичної вени. Темп інтраопераційної інфузії був розрахований виходячи з показників ударного об'єму (УО).

Нами проаналізовані показники центральної гемодинаміки, отримані математичним шляхом. Для розрахунку УО використовували формулу I. Starr:

$\mathrm{VO}($ мл $)=100+1 / 2 \times\left(\mathrm{AT}_{\text {сист. }}-\mathrm{AT}_{\text {діаст. }}\right)-0,6 \times \mathrm{AT}_{\text {діаст. }}-0,6 \times$ вік.

Інші показники центральної гемодинаміки були вирахувані математично за формулами [8]:

де $\mathrm{CB}$ - серцевий викид;

$$
\mathrm{CB}(л / \mathrm{Xв})=\mathrm{УO} \times \text { ЧСС, }
$$

де УІ - ударний індекс,

$$
\text { УІ = УО/ППТ, }
$$

ППТ - площа поверхні тіла, яку розраховували

за формулою Дюбуа і Дюбуа:

$$
\text { ППТ }=(\text { маса тіла } \times 0,423) \times(\text { зріст } \times 0,725) \times 0,007184 ;
$$$$
\mathrm{CI}\left(\text { л } / \mathrm{XB} \times \mathrm{M}^{2}\right)=\mathrm{CB} / \Pi \Pi \mathrm{T},
$$

де CI - серцевий індекс.

Статистичний аналіз результатів дослідження здійснювали в пакеті MedCalc v. 18.11 (MedCalc Software Inc, Broekstraat, Бельгія). Для представлення кількісних даних розраховували медіанне значення (Ме) показника та значення першого та третього квартилей $\left(Q_{I}-Q_{I I}\right)$. Для порівняння значення показника використано непараметричний критерій Т-Вілкоксона для пов'язаних вибірок [9], для оцінки показників розраховували 95\% вірогідний інтервал (95\% ВI). Для визначення зв'язку показників використано метод кореляційного аналізу (розраховували коефіцієнт лінійної кореляції - r) та метод побудови логістичних моделей регресії. Адекватність логістичної моделі регресії оцінювали за критерієм хі-квадрат та методом побудови кривої операційних характеристик (Receiver Operating Characteristic Curve - ROC-кривої) за площею під ROC-кривою (Area Under the Curve - AUC) [9]. Для визначення критичного порога ризику зміни показника СI використано показник Youden index [9], що дає можливість досягнути високих значень чутливості та специфічності 


\begin{tabular}{|c|c|c|c|}
\hline \multicolumn{4}{|c|}{ Значення показника СІ вихідне і на початку накладення карбоксиперитонеуму } \\
\hline \multirow[b]{2}{*}{ Показник } & \multicolumn{2}{|c|}{ Значення показника, $\mathrm{Me}\left(Q_{1}-Q_{\text {III }}\right)$} & \multirow[b]{2}{*}{$\mathrm{p}$} \\
\hline & $\begin{array}{c}\text { вихідне } \\
(\mathrm{n}=45)\end{array}$ & $\begin{array}{l}\text { на початку накладення карбоксиперитонеуму } \\
\qquad(\mathrm{n}=45)\end{array}$ & \\
\hline $\mathrm{Cl}, \pi / \mathrm{\prime B} \times \mathrm{M}^{2}$ & $1,887(1,461-2,228)$ & $1,478(1,082-1,759)$ & $<0,001$ \\
\hline \multicolumn{4}{|c|}{ Для порівняння використано критерій Т-Вілкоксона } \\
\hline
\end{tabular}

тесту. Прогностичні характеристики логістичної моделі регресії оцінювали за ії чутливістю, специфічністю, прогностичністю позитивного результату (ППР) та прогностичністю негативного результату (ПНР), розраховували відповідний 95\% ВІ. Щодо всіх показників визначено критичний рівень значущості відмінностей (p), рівний 0,05 .

\section{Результати}

На початку накладення карбоксиперитонеуму показник CI знизився у 35 та підвищився у 10 пацієнтів у порівнянні з його вихідним значенням ( $<<0,001)$. У середньому показник СІ знизився на 21,7\% (95\% BI 15,2\% - 32,9\%) (див. таблищю).

Проведеним кореляційним аналізом встановлено, що зміна абсолютного значення показника СI $(\Delta, \%)$ корелює iз величиною ВЧТ (рис. 1). Виявлено сильний позитивний лінійний зв'язок $(\mathrm{r}=0,83 ; \mathrm{p}<0,001)$ показника $\Delta$ та величини ВЧТ: на кожне зростання ВЧТ на 1 мм рт. ст. показник $\Delta$ зростав в середньому на $8,4 \%$.

Вважаючи, що зміна показника CI у межах 20\% є безпечною, а зміна більше 20\% може призвести до негативних наслідків ("випадок", що спостерігали у 29 пацієнтів) $[10,11]$, ми спробували визначити критичну величину ВЧТ, перевищення якої призводить до зростання ризику сильної зміни СI. Для проведення аналізу використано метод побудови логістичної моделі регресії та їі ROCкривої (рис. 2).

Однофакторна модель прогнозування ризику сильної зміни СI, побудована на показнику ВЧТ, адекватна ( $\Delta^{2}=48,1$, $\mathrm{p}<0,001) ; \mathrm{AUC}=0,98$ (95\% BI 0,89 - 1,00), що свідчить про тісний зв'язок ризику сильної зміни СІ із величиною ВЧТ.

Для визначення оптимальної критичної величини ВЧТ використано метод розрахунку Youden Index. Встановлено критичну величину ВЧТ - 15 мм рт. ст. (якщо ВЧТ більше 15 мм рт. ст., прогнозуємо "випадок", менше 15 мм рт. ст. прогноз сприятливий). Для вибору цієї критичної величини ВЧТ чутливість тесту становить 93,1\% (95\% ВI 77,2\% - 99,2\%), специфічність - 100\% (95\% ВI 79,4\% - 100\%), $\Pi \Pi$ П = 100\% (95\% ВI 93,2\% - 100\%), ПНР = 88,9\% (95\% BI $67,7 \%-96,8 \%)$.

\section{Обговорення}

Хворі з МО мають особливий серцево-судинний статус, а саме знижену скоротливість лівого шлуночка, підвищений тиск у легеневій артерії, знижений або, навпаки, підвищений СВ, підвищений загальний судинний опір [6].

Показано, що для пацієнтів з нормальною масою тіла верхньою безпечною величиною ВчТ в умовах карбоксиперитонеуму є 10 - 12 мм рт. ст. [5, 12, 13]. Величина ВЧТ у значній мірі впливає на візуалізацію черевної порожнини під час лапароскопічних втручань [14]. У нашому до-

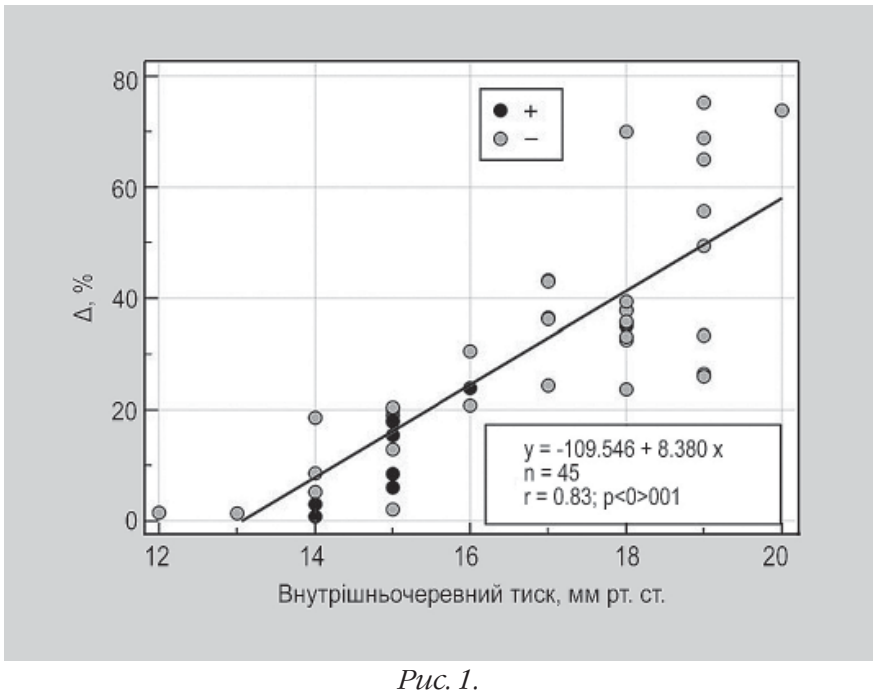

Поле кореляиї̈ зв'язку зміни абсолютного значення показника СІ на початку накладення карбоксиперитонеуму та величини ВЧТ.

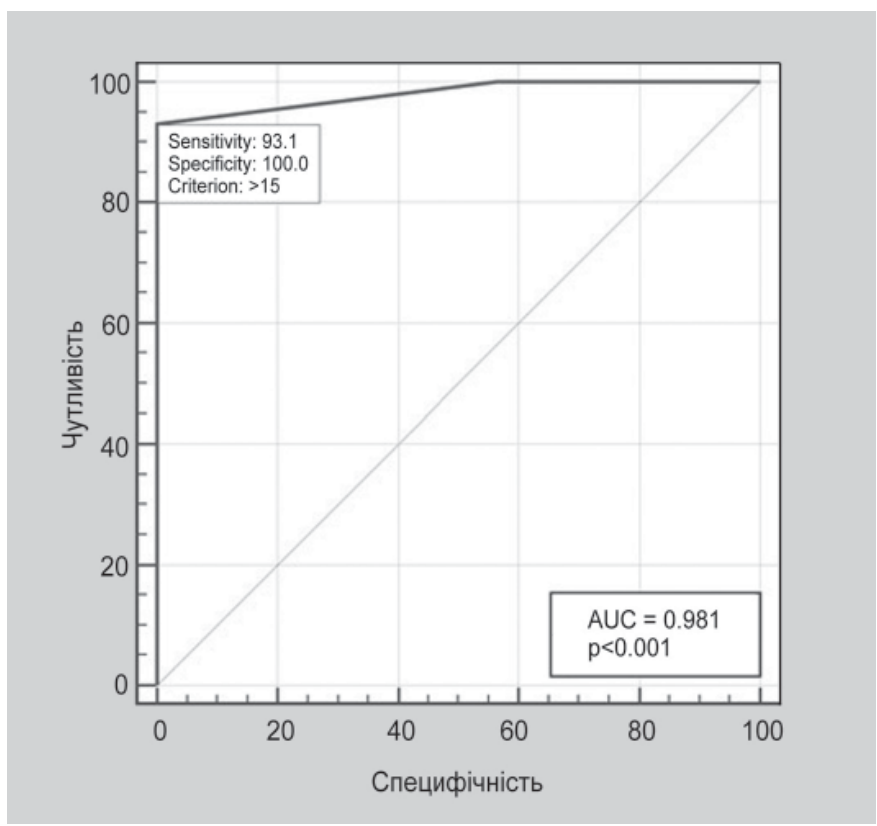

Puc. 2.

ROC-крива моделі прогнозування ризику сильноїзміни CI, побудована на показнику ВЧТ.

слідженні хірурги підвищували ВЧТ до 18 - 19 мм рт. ст. на початку інсуфляції газу з таких причин: по-перше, маса передньої черевної стінки у хворих з МО значно більша, ніж у хворих з нормальною масою тіла, тому для гарного огляду тиск повинен бути трохи вище, ніж у пацієнтів з нормальним IMT; по-друге, такий тиск забезпечує 
більш ефективний баростаз. Але підвищений ВЧТ є основним чинником серцевої депресії. Механізми зниження СВ після внутрішньочеревної інсуфляції газу включають збільшення постнавантаження і зниження переднавантаження, перешкоджаючи венозному поверненню [6, 7, 13].

У даному дослідженні виявлено негативний вплив підвищеного ВЧТ на показники центральної гемодинаміки у пацієнтів з МО та супутньою ССП під час лапароскопічних баріатричних втручань. Ми спостерігали у 35 хворих зниження CI, а у 10 хворих підвищення СI за рахунок збільшення ЧСС та $\mathrm{AT}_{\text {ср. }}$, йовірно обумовленого активацією баро- та хеморецепторів.

Визначено оптимальну величину ВЧТ 15 мм рт. ст., за якої спостерігали відновлення показників центральної гемодинаміки до вихідного рівня.

Карбоксиперитонеум за низького ВЧТ зводить до мінімуму несприятливі гемодинамічні ефекти, але не може забезпечити оптимальні хірургічні умови у хворих під час баріатричних втручань, тому за такого ВЧТ поставала проблема збільшення об’єму внутрішньочеревного простору.

У разі переведення пацієнта із зворотного положення Тренделенбурга на операційному столі в положення «в шезлонзі» до або під час накладення карбоксиперитонеуму збільшується об'єм внутрішньочеревного простору на 770 мл за умови повного нервово-м'язового блоку $[15,16]$. Крім того, в даному положенні покращується венозне повернення та збільшується СВ.

\section{Висновки}

1. У пацієнтів з МО під час лапароскопічних баріатричних втручань $є$ ризик інтраопераційних ускладнень, пов'язаних з використанням карбоксиперитонеуму.

2. Хірурги та анестезіологи, зайняті в лапароскопічній баріатричній хірургії, повинні розуміти ефекти карбоксиперитонеуму за наявності МО і вдаватися до відповідного інтраопераційного коригування для зведення до мінімуму несприятливих змін.

3. Тривалий карбоксиперитонеум за ВЧТ 15 мм рт. ст. і менше не призводить до значених гемодинамічних змін у хворих з МО та супутньою ССП і $є$ оптимальним для них: чутливість тесту 93,1\% (95\% ВI 77,2\% - 99,2\%), специфічність 100\% (95\% ВI 79,4\% - 100\%), ППР = 100\% (95\% BI 93,2\% - 100\%), ПНР=88,9\% (95\% ВI 67,7\% - 96,8\%).

4. Положення в «в шезлонзі» $є$ ідеальним положенням хворого на операційному столі під час лапароскопічних баріатричних втручань.

\section{Підтвердження}

\section{Фінансування}

Це дослідження є фрагментом планової НДР.

Фінансування за рахунок держбюджету.

\section{Інформація про внесок кожного учасника}

Внесок кожного автора в цю роботу однаковий. Всі автори прочитали і схвалили остаточний варіант рукопису.

\section{Конфлікт інтересів}

Автори, які взяли участь в цьому дослідженні, декларуЮть відсутність конфлікту інтересів щодо цього рукопису.

\section{Згода на публікацію}

Всі автори дали згоду на публікацію цього рукопису.

\section{References}

1. Dexter SP, Vucevic M, Gibson J, McMahon MJ. Hemodynamic consequences of high and low pressure capnoperitoneum during laparoscopic cholecystectomy. Surg Endosc.1999 Apr;13(4): 376-381.PMID: 10094751.

2. Umar A, Mehta KS, Mehta N. Evaluation of hemodynamic changes using different intra-abdominal pressures for laparoscopic cholecystectomy. Indian J Surg. 2013 Aug;75(4):284-9. http://doi.org/10.1007/ s12262-012-0484-X.

3. Ekici Y, Bozbas H, Karakayali F, Salman E, Moray G, Karakayali H, et al. Effect of different intra-abdominal pressure levels on QT dispersion in patients undergoing laparoscopic cholecystectomy. Surg Endosc 2009 Nov;23(11):2543-9. http://doi.org/10.1007/s00464-009-0388-4.

4. Meininger D, Byhahn C, Bueck M, Binder J, Kramer W, Kessler P et al. Effects of prolonged pneumoperitoneumon hemodynamics and acidbase balance during totally endoscopic robot-assisted radical prostatectomies. World J Surg. 2002 Dec;26 (12):1423-7. http://doi.org/10.1007/ s00268-002-6404-7.

5. McLaughlin JG, Scheeres DE, Dean RJ, Bonnell BW. The adverse hemodynamic effects of laparoscopic cholecystectomy. Surg Endosc. 1995 Feb;9 (2):121-4. PMID: 7597577.

6. Nguyen NT, Wolfe BM . The physiologic effects of pneumoperitoneum in the morbidly obese. Ann Surg. 2005 Feb;241(2):219-26. PMID: 15650630 .

7. Sharma A, Dahiya D, Kaman L, Saini V, Behera A. Effect of various pneumoperitoneum pressures on femoral vein hemodynamics during laparoscopic cholecystectomy. Updates Surg. 2016 Jun;68(2):163-9. http://doi.org/10.1007/s13304-015-0344-x.

8. Stelfox H, Ahmed SB, Ribeiro RA, Gettings EM, Pomerantsev E, Schmidt U. Hemodynamic monitoring in obese patients: the impact of body mass index on cardiac output and strock volume. Crit Care Med. 2006 Apr;34(4):1243-6. http://doi.org/10.1097/01.CCM.0000208358.27005. F4.

9. Gurianov VG, Liakh YuYe, Parii VD, Korotkyi OV, Chalyi OV, Chalyi KO, Tsekhmister YaV. Posibnyk z biostatystyky. Analiz rezultativ medychnykh doslidzhen u paketi EZR (R-Statistics): Navch posib. K.: Vistka; 2018. 208 s. [In Ukrainian].

10. Barczyn'ski M, Herman RM. Influence of different pressures of pneumoperitoneum on the autonomic system function during laparoscopy. Folia Med Cracov 2002;43(1-2):51-8. PMID: 12815798.

11. Sandhu T, Yamada S, Ariyakachon V, Chakrabandhu T, Chongruksut W, Ko-Iam W. Low-pressure pneumoperitoneum versus standard pneumoperitoneum in laparoscopic cholecystectomy: a prospective randomized clinical trial. Surg Endosc. 2009 May;23(5):1044-7. http://doi org/10.1007/s00464-008-0119-2.

12. D'Ugo D, Persiani R, Pennestri F, Adducci E, Primieri P, Pende V, et al. Transesophageal echocardiographic assessment of hemodynamic function during laparoscopic cholecystectomy in healthy patients. Surg Endosc. $2000 \mathrm{Feb}$;14(2):120-2. PMID: 10656941.

13. Mertens zur Borg IR, Lim A, Verbrugge SJ, IJzermans JN, Klein J. Effect of intraabdominal pressure elevation and positioning on hemodynamic responses during carbon dioxide pneumoperitoneum for laparoscopic donor nephrectomy: a prospective controlled clinical study. Surg Endosc. 2004 Jun;18 (6):919-23. http://doi.org/10.1007/s00464-003-8817-2

14. Angioli R, Terranova C, Plotti F, Cafä EV, Gennari P, Ricciardi R et all. Influence of pneumoperitoneum pressure on surgical field during robotic and laparoscopic surgery: a comparative study. Arch Gynecol Obstet. 2015 Apr;291(4):865-8. http://doi.org/10.1007/s00404-014-3494-z.

15. Mulier JP, Dillemans B, Van Cauwenberge S. Impact of the patient's body position on the intraabdominal workspace during laparoscopic surgery. Surg Endosc. 2010 Jun;24(6):1398-402. http://doi.org/10.1007/ S00464-009-0785-8

16. Rosenberg J, Herring WJ, Blobner M, Mulier JP, Rahe-Meyer N, Woo $\mathrm{T}$, et al. Deep Neuromuscular Blockade Improves Laparoscopic Surgical Conditions: A Randomized, Controlled Study. Adv Ther. 2017 Apr;34(4):925-36. http://doi.org/10.1007/s12325-017-0495-x.

Надішла 15.11.2018 